A RCHIWA, BIBLIOTEKI

I MUZEA KOŚCIELNE 112 (2019)

https://doi.org.10.31743/abmk.2019.112.11

\title{
KSIĘGOZBIÓR KANONIKÓW I WIKARIUSZY KAPITUEY KOLEGIACKIEJ PW. NARODZENIA NMP W TARNOWIE (XV-XVIII W.) W ZBIORACH BIBLIOTEKI TARNOWSKIEGO SEMINARIUM DUCHOWNEGO
}

\section{Streszczenie}

Od czasu powstania kolegiaty tarnowskiej (1400) gromadzony był podręczny księgozbiór, niezbędny w pracy duszpasterskiej, zawierający Biblię i jej komentarze, traktaty filozoficzne i teologiczne, a także księgi pomocne w kaznodziejstwie, w tym traktaty z zakresu teologii polemicznej. Systematycznie powiększał się, zwłaszcza dzięki darom i legatom testamentowym tarnowskich kanoników. Wśród ksiąg po kanonikach tarnowskich dają się wyróżnić dwie znaczące i cenne pod względem zawartości kolekcje: kanoników Szymona Starowolskiego i Erazma Marcinowskiego z charakterystycznymi oprawami ksiąg dla obu kolekcji. Są to dzieła z zakresu historii, kaznodziejstwa, prawa, biblistyki, a nade wszystko liturgiki. Drukowane są w języku łacińskim i pochodzą w zdecydowanej większości z zagranicznych oficyn wydawniczych: Paryża, Antwerpii, Bazylei, Wenecji, Rzymu i Werony.

Oprócz zgromadzonego księgozbioru kapitulnego księgi posiadało również kolegium wikariuszów utworzone przy kolegiacie tarnowskiej 10 lipca 1458 roku. Zgromadzone przez nich księgi pełniły funkcję praktyczną, służąc pomocą w duszpasterstwie parafialnym, na co wskazuje duża liczba sermones, homiliariów, wszelkiego rodzaju thesarusy i nade wszystko Biblia. Był to rodzaj księgozbioru podręcznego, służącego przede wszystkim do głoszenia kazań niedzielnych i w okresach roku liturgicznego. Księgi kolegium wikariuszów z czasem zasiliły księgozbiór kapituły kolegiackiej, a następnie katedralnej tarnowskiej. W XIX wieku, gdy tworzono bibliotekę seminarium tarnowskiego, księgi po wikariuszach kolegiackich zostały przekazane do księgozbioru seminaryjnego, gdzie znajdują się do dzisiaj.

Słowa kluczowe: Tarnów; kolegiata; kanonicy; kapituła kolegiacka; wikariusze; księgozbiór

* Jolanta Małgorzata Marszalska - prof. historii; Instytut Nauk Historycznych; Uniwersytet Kardynała Stefana Wyszyńskiego; e-mail: jmmarszalska@wp.pl

https://orcid.org/0000-0002-5112-5984 
Kapituły jako instytucje kościelne były kierowane i porządkowane ogólnymi zasadami prawa kościelnego, jednak jako korporacje o szczególnym charakterze wymagały własnych i bardziej szczegółowych norm prawnych, regulujących ich życie i działalność ${ }^{1}$. Na przestrzeni dziejów kapituły katedralne i kolegiackie odgrywały ważną rolę, zarówno gospodarczą, kulturową, jak i religijną. Fundowane były najczęściej w liczących się ośrodkach życia politycznego, gospodarczego, a z czasem kulturowego, a ich celem było uświetnienie kultu Bożego. Skupiały dobrze wykształcone duchowieństwo ze stopniami naukowymi, często uzyskanymi w znaczących, europejskich ośrodkach uniwersyteckich (Padwa, Bolonia, Paryż), a także w kraju (Akademia Krakowska). Po odbyciu studiów zagranicznych kanonicy często przywozili ze sobą księgi, które z czasem stawały się zrębem zasadniczym bibliotek kapitulnych.

Jednym z ważnych zadań kapituł katedralnych i kolegiackich była troska o poziom wykształcenia, stąd często zakładano przy nich szkoły, których funkcjonowanie i działalność trudno wyobrazić sobie bez książki. Troska o miejscową szkołę należała zawsze do scholastyka. To on $\mathrm{z}$ reguły zatrudniał i rozwiązywał stosunek pracy z rektorem szkoły, z bakałarzem, a nieco później z kantorem. Scholastyk był też odpowiedzialny za gromadzenie ksiąg niezbędnych do nauczania. Stawały się one później podstawą do powstania bibliotek. Ich zasobność zależna była od zamożności kapituł i zainteresowań kanoników. Biblioteki często rozwijały się w wyniku darowizn, czynionych tak za życia, jak i legowanych w formie zapisu testamentowego. Wśród ofiarodawców byli nie tylko kanonicy kapituł, lecz także osoby związane z nimi w jakikolwiek sposób.

I choć różny był czas i okoliczności powstawania kapituł kolegiackich w: Tarnowie $(1400)^{2}$, Nowym Sączu (1448) $)^{3}$, Wojniczu (1465) 4 czy Bobowej (1529) to zachowane fragmenty księgozbiorów po kanonikach tychże kapituł oddają poziom intelektualno-kulturowy członków kapituły, zainteresowania nowinkami teologicznymi ich czasów, kwoty, jakie przyszło im uiszczać za poszczególne woluminy, a także funkcje, jakie sprawowali za życia. Ich większe bądź czasami znikome księgozbiory własne stawały się podstawą dla powstawania bibliotek ${ }^{6}$.

${ }^{1}$ S. Zachorowski, Rozwój i ustrój kapituł polskich w wiekach średnich, Kraków 1912, s. 179.

${ }^{2}$ Kapituła kolegiacka w Tarnowie erygowana w 1400 r. nie doczekała się osobnego opracowania naukowego, najwięcej informacji na jej temat czerpiemy z dawnego opracowania F. Herziga, Katedra niegdyś kolegiata w Tarnowie wraz z krótka wzmianka o innych kościołach tarnowskich, Tarnów 1900.

${ }^{3}$ S. Salaterski, Kolegiata i kapituła św. Matgorzaty P.M. w Nowym Sączu (1448-1791), Nowy Sącz 1977.

${ }^{4}$ J. Szymański, Kapituła kolegiacka w Wojniczu 1465-1788, Lublin 1962.

${ }^{5}$ B. Kumor, Erekcja kolegiaty i kapituły pod wezwaniem Wszystkich Świętych w Bobowej, „Archiwa, Biblioteki i Muzea Kościelne" (dalej: ABMK), 11 (1965) s. 287-312.

${ }^{6}$ J.M. Marszalska, W. Graczyk, Zespoły proweniencyjne zasobu inkunabułów i starych druków Biblioteki Wyższego Seminarium Duchownego w Tarnowie. Właściciele, użytkownicy, bibliofile, Warszawa 2017, s. 126-127. Według J. Kaliszuka dotychczasowe badania nad bibliotekami kolegiackimi zdominowane zostały przez studium przypadku przez stosunkowo najlepiej rozpoznaną na podstawie omówienia trzech inwentarzy XV-wiecznych biblioteki kolegiackiej w Wiślicy. Wyniki badań nad tym księgozbiorem uznawane są za reprezentatywne dla innych bibliotek kolegiackich. Problem ten również w swoich badaniach poruszała M. Hornowska, pisząc o całkowitym braku 


\section{Księgozbiór kanoników kapituły kolegiackiej w Tarnowie}

Kościół kolegiacki w Tarnowie został wzniesiony w pierwszej połowie XIV wieku. Od początku nosił wezwanie Narodzenia Najświętszej Maryi Panny. W 1400 roku biskup krakowski Piotr Wysz podniósł świątynię do godności kolegiaty i erygował przy niej kapitułę z trzema prałaturami (prepozyt, kustosz, kantor) i dwiema kanoniami:

[...] Petrus Wisch cracoviensis episcopus devota Iohannes de Tarnow palatini Sendomiriensis [...] in oppido Tarnow [...] Anno Domini Millesimo Quadringentesimo, Collegiatam creat et tres Praelaturas, videlicet Preposituram, $\mathrm{Cu}-$ stodiam et [...] Cantoriam. Item duas canonias [...] $]^{7}$.

Trzecia kanonia, zwana kanonią łukowską, została ufundowana przez kasztelana i starostę krakowskiego Jana Tarnowskiego i jego brata Spytka w 1415 roku. W 1498 roku kardynał Fryderyk Jagiellończyk utworzył przy kolegiacie tarnowskiej kanonię tytularną św. Barbary, którą uposażył zniesionym beneficjum parafii pw. Matki Bożej Pocieszenia w Wierzchosławicach. W miejsce parafii w Wierzchosławicach utworzył tzw. wikariat wieczysty. Pod koniec XVIII wieku (1772) kapituła kolegiacka liczyła 7 prałatur i 13 kanonii ${ }^{8}$.

W połowie XV wieku (10 lipca 1458) biskup krakowski Tomasz Strzępiński erygował przy kolegiacie kolegium siedmiu wikariuszów, których zadaniem była troska o duszpasterstwo parafialne:

[...] Proinde nos Thomas Dei gratia Episcopus cracoviensis universis et singulis presentibus et futuris presentium notitiam habitans per graventes significamus. Quomodo Honorabiles Nicolaus de Radłow Praepositus, Ioannes de Tarnow Custos, Stanislaus de Krzemieniewo Cantor, Ioannes de Zagosc, Nicolaus de Posnaniae, Mathias de Radzankow, Prelati et Canonici ecclesiae collegiatae Sancta Mariae in Tharnow in nostra constituti personaliter presentia exposuerunt [...] cum Generoso Ioanne Amor de Tharnow et Patrono eorundem beneficiorum habita deliberatione cupientes augere cultum divinum septem vicarias perpetuas in titulum perpetui beneficiis pro septem Presbyteris $[\ldots]$ fundare $[\ldots]^{9}$.

Półtora wieku później, w 1609 roku, książę Janusz Ostrogski uposażył kolegium mansjonarzy, które erygował w 1611 roku biskup Piotr Tylicki. W 1620 roku książę Teofil Ostrogski uposażył kolegium psałterzystów, a erygował je w 1621 roku biskup Marcin Szyszkowski ${ }^{10}$.

podstawy umożliwiającej orientację w zawartości treściowej tych księgozbiorów. Por. J. Kaliszuk, Codices deperditi. Średniowieczne rękopisy tacińskie Biblioteki Narodowej utracone $w$ czasie II wojny światowej, t. 1: Dzieje i charakterystyka kolekcji, Wrocław 2016, s. 481; M. Hornowska, H. Zdzitowiecka-Jasieńska, Zbiory rękopiśmienne w Polsce średniowiecznej, Warszawa 1947, s. 297-300.

${ }^{7}$ Archiwum Diecezji Tarnowskiej (dalej: ADT), Erectio ecclesiae colegiatae Tarnoviensis descripta, w: Documenta ecclesiae collegiatae tarnoviensis, sygn. I. 3, k. 206; zob. Marszalska, Graczyk, Zespoty proweniencyjne, s. 127

${ }^{8}$ Herzig, Katedra niegdyś kolegiata w Tarnowie, s. 23.

${ }^{9}$ ADT, Privilegium erectionis vicariorum Tharnoviensem in titulum perpetuitatis, w: Documenta ecclesiae collegiatae tarnoviensis, sygn. I. 3, k. 1-8.

${ }^{10}$ Marszalska, Graczyk, Zespoty proweniencyjne, s. 128-129. 
Około 1560 roku ks. Marcin Łyczko (1508-1578) ${ }^{11}$, prepozyt kapituły kolegiackiej w Tarnowie, wybudował - w miejsce wcześniejszego drewnianego - murowany budynek z przeznaczeniem dla szkoły kolegiackiej. Równocześnie wystarał się od władz miasta o stałą dotację w kwocie czterech grzywien rocznie, z przeznaczeniem na utrzymanie bakałarza szkoły, od hetmana Jana Tarnowskiego zaś dziesięciny z pól folwarcznych w Borowicach i Nagoszynie. Działania prepozyta przyczyniły się do podniesienia poziomu kształcenia w szkole kolegiackiej, tym bardziej iż osobiście zapisem testamentowym przeznaczył 1000 zł polskich na stypendium dla trzech studentów uczących się w Akademii w Krakowie z jednoczesnym ich zobowiązaniem do powrotu po zakończonej nauce do Tarnowa i podjęcia obowiązków nauczyciela w szkole kolegiackiej ${ }^{12}$.

Od czasu powstania kolegiaty tarnowskiej gromadzony był podręczny księgozbiór, przechowywany w skarbcu kolegiackim wraz z paramentami liturgicznymi $\mathrm{w}$ specjalnie do tego celu przeznaczonych szafach. Były to niezbędne w pracy duszpasterskiej księgi liturgiczne: Biblia i jej komentarze, traktaty filozoficzne i teologiczne, a także dzieła pomocne w kaznodziejstwie. Odnotowana była też obecność ksiąg liturgicznych i traktatów z zakresu teologii polemicznej. Niemal do końca XV stulecia były to manuskrypty, a pierwsze informacje na temat niewielkiego jeszcze zasobu ksiąg kapituły tarnowskiej pochodzącą z końca XVI wieku i zamieszczone są w wizytacji kardynała Jerzego Radziwiłła z 1597 roku.

Zachowane do dziś księgi pokapitulne ${ }^{13}$ to: mszały rzymskie, kanony, pontyfikał, księgi o treści teologicznej, dzieła ojców Kościoła, dzieła z zakresu kaznodziejstwa i traktaty prawnicze ${ }^{14}$. Były one niezbędne w sprawowaniu liturgii mszy św., kaznodziejstwie i szeroko pojętej pracy duszpasterskiej. Nie zachował się inwentarz ksiąg kapituły kolegiackiej w Tarnowie, na podstawie którego można byłoby przeprowadzić analizę treści tematycznej i autorskiej zgromadzonego w ciągu wieków księgozbioru. Księgozbiór kolegiaty tarnowskiej przekazywano sukcesywnie od końca XIX stulecia do zbiorów biblioteki Seminarium Duchownego w Tarnowie. Analiza ksiąg pokapitulnych (obecnie seminaryjnych), a nade wszystko zapisów proweniencyjnych na poszczególnych dziełach pozwoliła na wyodrębnienie zbioru ksiąg o różnej tematyce, a także jej dawnych właścicieli kanoników kapituły tarnowskiej. Pozostawiali oni często na księgach (do nich należących bądź przez nich użytkowanych) wpisy własnościowe, za pomocą których dawne księgi można powiązać od strony historycznej z konkretną osobą. Są to bardzo istotne informacje, dzięki którym czerpiemy wiedzę o mentalności dawnych właścicieli, ich zainteresowaniach, a także gromadzeniu niezbędnych ksiąg do pracy duszpasterskiej czy prawniczej. Przykładem jest zachowane dzieło

${ }^{11}$ Z. Ruta, Eyczko Marcin h. Sulima (1508-1578), w: Polski Stownik Biograficzny (dalej: PSB), t. 17, red. E. Rostworowski, Wrocław-Warszawa-Kraków 1973, s. 595.

${ }^{12}$ Tamże.

${ }^{13}$ Księgi po kanonikach kapituły tarnowskiej, jak również po kolegium wikariuszów kolegiaty tarnowskiej przechowywane są obecnie w zbiorach Biblioteki Wyższego Seminarium Duchownego w Tarnowie. Z kolegiaty tarnowskiej (później katedry) księgozbiór pokanonicki był sukcesywnie przekazywany od końca XIX wieku do zbiorów biblioteki seminaryjnej, tworząc jego znaczący zasób. Księgi te obecnie mają nadaną sygnaturę bieżącą Biblioteki WSD w Tarnowie, na wielu zaś zachowały się jeszcze dawne sygnatury ich przynależności do biblioteki kolegiackiej w Tarnowie.

${ }^{14}$ Marszalska, Graczyk, Zespoly proweniencyjne, s. 130-131. 
Matthiasa Martineza, Opera s. Matris Teresae [...], wydane w Kolonii w 1636 roku. W XVII stuleciu jej właścicielem był Marcin Lyskowicz (Liskowicz), posiadający w latach 1653-1662 kanonię tytułu pw. Panny Maryi Wniebowziętej na Burku (w Tarnowie) ${ }^{15}$. Na karcie tytułowej dzieł zebranych św. Teresy od Jezusa odnotował: Martinus Lyskowicz, canonicus ecclesiae Collegiatae Tarnoviensis ${ }^{16}$. Kanonik Marcin Liskowicz był również w posiadaniu XV-wiecznej księgi, niezwykle popularnej w środowisku kościelnym - Legenda aurea, autorstwa Jakuba $\mathrm{z}$ Voraginy wydanej w Bazylei w 1486 roku $^{17}$. Otrzymał ją w bliżej nieznanych okolicznościach od plebana skrzyszowskiego Jana Bieleckiego, co zostało odnotowane na karcie tytułowej dzieła: „Sum Joannis Bieleczki plebani Skrzissouviensis - zaś nieco poniżej - Martinus Lyskowicz Canonicus Tarnovien. Eccl. Tarnoviensi offert." ${ }^{\prime 18}$. Tak było również w przypadku dzieła Pymander Mercurii Trismegisti cum commento fratris Hannibalis Rosseli [...], wydanego w Krakowie w 1586 roku. Początkowo księga była w posiadaniu Jana Dymitra Solikowskiego - od 1583 roku arcybiskupa lwowskiego ${ }^{19}$. Dnia 25 stycznia 1594 roku dzieło zostało podarowane przez arcybiskupa jego kapelanowi, ks. Janowi Skorkowiczowi, świadczy o tym zachowany wpis:

Illustrissimus ad Reverendissimus in Christo [...] Ioannis Demetrius Solikowskij a Solikij Dei Gratia archiepiscopus Leopoliensis Ioanni Skorkovicio Coprovicensis sacerdotis et capellano suo [...] librum hunc detto Anno 1594 menso 25 januarij $^{20}$.

Następnie Jan Skorkowicz podarował ją ks. Jakubowi Śliwskiemu (zm. 1638), od 1603 roku proboszczowi w Laszkach k. Jarosławia. Ksiądz Jakub Śliwski w 1619 roku uzyskał kantorię w kapitule kolegiackiej w Tarnowie, w 1626 roku zaś - archidiakonię w kapitule katedralnej w Przemyślu ${ }^{21}$. O tym, że wszedł w posiadanie omawianego dzieła, świadczy następujący zapis proweniencyjny: „Reverendus [...] Ioannis Skorkovicius plebanus [...] mihi Iacobo Śliwski [...] in perpetui signus amoris dedit [...] mpp. Oretur pro eo"22. Prawdopodobnie po śmierci kantora tarnowskiego Jakuba Śliwskiego księga trafiła do zbiorów biblioteki kapitulnej. Podobnie było z dziełem jest Stanisława Hozjusza Verae chri-

${ }^{15}$ Marcin Liskowicz (Lyskowicz) był w kapitule kolegiackiej w Tarnowie kanonikiem tytułu Panny Maryi Wniebowziętej w kościele na Burku w Tarnowie w 1. 1653-1662. W 1660 r. zapisał kanonikowi kaznodziei 3 złp. stałego rocznego dochodu za wypominki swojej duszy po kazaniach. Zob. Herzig, Katedra niegdyś kolegiata, s. 52, 55; J.M. Marszalska, Katalog inkunabutów biblioteki Wyższego Seminarium Duchownego w Tarnowie, Tarnów 1997, s. 116.

${ }^{16}$ Biblioteka Wyższego Seminarium Duchownego w Tarnowie/ Stare Druki (dalej: BWSDT/ SD), sygn. 3163.

${ }^{17}$ Biblioteka Wyższego Seminarium Duchownego w Tarnowie/ Inkunabuły (dalej: BWSDT/ INC), sygn. 56. Zob. Marszalska, Katalog inkunabułów biblioteki, s. 62, poz. 82.

${ }^{18}$ Tamże.

${ }^{19}$ W. Rosowski, Solikowski Jan Dymitr (1539-1603), w: Encyklopedia katolicka, t. 18, red. E. Gigilewicz, Lublin 2013, kol. 580-581.

${ }^{20}$ BWSDT/SD, sygn. 5668.

${ }^{21}$ T. Śliwa, Śliwski Jakub (zm. 1638), w: Encyklopedia katolicka, t. 19, red. E. Gigilewicz, Lublin 2013, kol. 254-255; Herzig, Katedra niegdyś kolegiata, s. 21; Marszalska, Graczyk, Zespoły proweniencyjne, s. 131.

${ }^{22}$ BWSDT/SD, sygn. 5668. 
stianae catholicaeque doctrinae solida propugnatio una cum illustri confutatione Prolegomenorum [...], które zostało wydane w Antwerpii w 1558 roku $^{23}$. Warto zaznaczyć, że księga została zakupiona w 1559 roku przez kasztelana sandomierskiego Stanisława Tarnowskiego (zm. 1618), fakt ten potwierdza zachowany wpis proweniencyjny: ,Stanislaus Tharnowski anno domini 1559 pro nundinis Sancti Petri Premislensis emptus gross.46"24.

W ciągu wieków dzieło miało wielu właścicieli. Świadczą o tym następujące w kolejności wpisy proweniencyjne: „Fr. Petrus donatus Rev. Dominus Lucas Gnaszowski Can. Cracov. donavit.”, poniżej zapisano: „Fr. Lucas Gnaszowski donavit conv. S. Francisci Rev. in Dno Clementi Scalbimiriensis dedit donavit amoris gratia mpp.”, poniżej odnotowano: „Fr. Clemens Scalbimiriensis fratri Hipolito Pilsnensis dono oretur pro eo”; ostatni zapis: „Fr. Hipolitus dono conv. Varsoviensis mpp" ${ }^{25}$. W bliżej nieznanych okolicznościach księga znalazła się rękach wspomnianego Marcina Liskowicza, kanonika kapituły kolegiackiej, ten zaś podarował ją, prawdopodobnie u schyłku swojego życia, kościołowi tarnowskiemu, co zaświadczył wpisem: „Marthinus Lyskowicz, canonicus Tarnoviensis, ecclesiae Tarnoviensis offert." Zapewne miało to miejsce ok. 1660 roku, jeszcze bowiem tego roku Marcina Liskowicz zapisał 3 złp stałego rocznego dochodu za wypominki swojej duszy po kazaniach kanonikowi i kaznodziei kolegiackiemu ${ }^{26}$. Warto podkreślić, iż na czystych, przedtytułowych kartach zachowały się liczne wpisy i komentarze odnoszące się do treści dzieła.

Do zbiorów kapitulnych przekazał również księgę Georgiusa Edenusa Oeconomia Bibliorum [...] (Kolonia 1568) prepozyt i oficjał Albert Karol Czalański. Fakt ten został potwierdzony niedatowaną adnotacją widniejącą na karcie tytułowej księgi: „Iste liber donatus est Bibliothecae Collegiatae Tarnoviensis Rndo Alberto Carolo Czalański, praeposito et officialis"27. Z kolei z treści zapisu na kaznodziejskim dziele Philipa Diaza Conciones Quadruplices [...] (Wenecja 1603) ${ }^{28}$ wiadomo, iż nabył je inny kanonik tarnowski Stanisław Józef Marczewski ${ }^{29} 7$ listopada 1666 roku, po śmierci księdza Baczkowskiego. Fakt ten poświadcza pozostawiona nota na karcie tytułowej wspomnianego dzieła: „Sum Stanislai Josephi Marczewski emptus post obitum Rndi P. Baczkowski 7 novembris $1666 " 30$.

$\mathrm{Z}$ kolei dzieło Scholastica commentaria in primam partem [...] autorstwa Dominika Baneza, wydane w Lyonie w 1588 roku $^{31}$, należało najpierw do kanonika sandomierskiego Pawła Złomańskiego, a następnie kanonika kolegiaty tarnow-

${ }^{23}$ BWSDT/SD,sygn.595. Zob. J. Misiurek, Hozjusz Stanisław (1504-1579), w: Encyklopedia katolicka, t. 6, red. J. Walkusz, Lublin 1993, kol. 1257-1260.

${ }^{24}$ BWSDT/SD, sygn.595.

${ }^{25} \mathrm{BWSDT} / \mathrm{SD}$, sygn. 595.

${ }^{26}$ Herzig, Katedra niegdyś kolegiata w Tarnowie, s. 55.

${ }^{27}$ BWSDT/SD, sygn. 534.

${ }^{28}$ BWSDT/SD, sygn. 312432.

${ }^{29}$ Stanisław Józef Marczewski był prepozytem w Bochni i plebanem w Brzeźnicy. W kapitule kolegiackiej w Tarnowie prałat dziekan od 27 lipca 1697 do 24 sierpnia 1699 roku, a następnie prałat kustosz od 25 sierpnia 1699 do 1705 roku (do śmierci). Zob. Herzig, Katedra niegdyś kolegiata, s. 20.

${ }^{30}$ Marszalska, Graczyk, Zespoły proweniencyjne, s. 132.

${ }^{31}$ BWSDT/SD, sygn. 5120. 
skiej - Kazimierza Leszkowicza. Fakt ten poświadczają zachowane wpisy proweniencyjne na karcie tytułowej dzieła: „Ex libris Pauli Złomanski, canonici Sandomiriensis, plebani Miechoviensis”, dalej odnotowano: „Tandem Casimiro Leszkowicz, canonico Tarnoviensis, decano Miechoviensis, plebano Ranizoviensis [...]"32. Kanonik Kazimierz Leszkowicz był instalowany w kapitule tarnowskiej 26 sierpnia 1700 roku, zmarł w 1719 roku. Zatem księga stała się jego własnością po $1700 \mathrm{roku}^{33}$. Wiadomo również, że dzieło Wilhelma Buriusa Romanorum Pontificum [...] (Wenecja 1757) należało w przeszłości do zbiorów kanonika Antoniego Skibińskiego, co zapisano: „Ex Bibliothecae Antoni Skibiński canonicus cathedralis Tarnoviensi”, następnie do księży: Franciszka Górskiego, Andrzeja Galińskiego, na końcu zaś do Andrzeja Tomiczka, co również odnotowano: „Hic liber donatus est mihi a Reverendo Andrea Tomiczek [...] pro tunc scholarum Gymnasialum Tarnoviensem 1812"34. Warto nadmienić, iż Antoni Skibiński (1736-1816) ${ }^{35}$ przed 1780 rokiem został mianowany kanonikiem w kapitule kolegiackiej w Bobowej, nieco później - 7 stycznia 1782 roku - kanonikiem kapituły kolegiackiej w Tarnowie. Był cenionym wizytatorem dekanatu żmigrodzkiego (1783) i oświęcimskiego (1792) $)^{36}$.

Wśród zachowanych $\mathrm{w}$ bibliotece seminarium tarnowskiego ksiąg po kanonikach tarnowskich dają się wyróżnić dwie znaczące i cenne pod względem zawartości kolekcje: kanoników Szymona Starowolskiego i Erazma Marcinowskiego z charakterystycznymi oprawami ksiąg dla obu kolekcji. Przechowywane obecnie w bibliotece seminaryjnej księgi z proweniencją Szymona Starowolskiego $^{37}$ (15 tytułów w 10 woluminach) to dzieła z zakresu historii, kaznodziejstwa,

32 Tamże.

${ }^{33}$ Kazimierz Leszkowicz był dziekanem miechowskim, plebanem w Borowej i Raniszowie. W kapitule kolegiackiej w Tarnowie kanonik - prebendarz tytułu Panny Maryi na zamku tarnowskim od 26 lipca 1700 roku do śmierci. Zob. Herzig, Katedra niegdyś kolegiata, s. 22.

${ }^{34}$ BWSDT/SD, sygn. 21253.

${ }^{35}$ Antoni Skibiński (1736-16 IV 1816), studia humanistyczne i filozoficzne ukończył w kolegium pijarskim w Podolińcu; teologię studiował w Krakowie; święcenia kapłańskie otrzymał 31 marca 1759 roku w Krakowie. W Akademii Krakowskiej uzyskał doktorat obojga praw i teologii. Do 1761 roku pracował jako wikariusz przy kościele mariackim w Krakowie; w 1766 roku został prepozytem i proboszczem w Dębowcu k/Jasła, w 1784 roku zaś - dziekanem żmigrodzkim. Przed 1772 rokiem został kanonikiem inflanckim, przed 1780 rokiem kanonikiem w kapitule bobowskiej, od 1782 roku - kanonik kapituły tarnowskiej. Z nominacji bpa F.A. Janowskiego został kanonikiem honorowym kapituły katedralnej w Tarnowie; od 30 maja 1790 - kanonikiem gremialnym kapituły katedralnej w Tarnowie. W 1804 został proboszczem kościoła katedralnego w Tarnowie. Po zniesieniu diecezji tarnowskiej został mianowany kanonikiem kapituły katedralnej w Kielcach. Zob. B. Kumor, Diecezja Tarnowska. Dzieje ustroju i organizacji 1786-1985, Kraków 1985, s. 20, 310, 387,455 .

${ }^{36}$ Marszalska, Graczyk, Zespoły proweniencyjne, s. 133-134.

${ }^{37}$ Księgozbiór Szymona Starowolskiego został opracowany i omówiony w publikacji: J.M. Marszalska, Starovolsciana w zbiorach starych druków Biblioteki Wyższego Seminarium Duchownego w Tarnowie, ,Rocznik Biblioteki Narodowej”, 44 (2013) s. 303-315 oraz w poszerzonej i uzupełnionej wersji w publikacji książkowej: Marszalska, Graczyk, Zespoły proweniencyjne zasobu inkunabutów i starych drukówi, s. 137-144. Wcześniej taką próbę omówienia kolekcji ksiąg po Szymonie Starowolskim - w wielu wypadkach błędną - podjął A. Nowak w artykule Książki z biblioteki Szymona Starowolskiego w Tarnowie, „Roczniki Biblioteczne”, 13 (1969) s. 106. 
prawa, biblistyki, a nade wszystko liturgiki. Wszystkie są wydrukowane w języku łacińskim i pochodzą $\mathrm{w}$ zdecydowanej większości z zagranicznych oficyn wydawniczych: Paryża, Antwerpii, Bazylei, Wenecji, Rzymu i Werony. Zaledwie jedna (z tej kolekcji ksiąg) została wydrukowana w oficynie krakowskiej, tzw. Łazarzowej. Jest to dzieło Stanisława Sokołowskiego In Evangelia Mathaei, Marci et Lucae [...] (Kraków 1598) ${ }^{38}$. Posiadanie tych dzieł Szymon Starowolski zawdzięczał licznym kontaktom naukowym, m.in. z uniwersytetami i oficynami wydawniczymi, które nawiązał podczas swoich podróży po Europie. Na księgach pozostawionych przez Szymona Starowolskiego widnieje własnoręczny, niedatowany wpis ich ofiarodawcy dla kościoła kolegiackiego: „Simon Starowolski Cantor Tarnoviensis Eccl.Collegiatae Tarnoviensi offert. mpp.”. Zachowane do dziś dzieła po Szymonie Starowolskim oprawione są w jasnożółty pergamin o gładkiej powierzchni, posiadają jedynie wiązania bądź ich zachowane fragmenty.

Obok znaczącej kolekcji ksiąg po kantorze Szymonie Starowolskim duży i cenny zbiór pozostawił po sobie również kanonik Erazm Marcinowski (Marczinowski), który w 1577 roku uzyskał stopień bakałarza artium liberales w Akademii Krakowskiej za dziekanatu Marcina Jana Ujazdowskiego ${ }^{39}$. Będąc kanonikiem kolegiaty tarnowskiej, zapewne jeszcze za życia przekazał księgi do biblioteki kapitulnej, o czym świadczy jednoznaczny zapis widniejący na kartach tytułowych legowanych przez niego dzieł: „M. Erasmus Marczinowski canonicus ecclesiae collegiatae Tarnovinsis legavit" ${ }^{\prime 4}$.

$\mathrm{Na}$ księgach pochodzących ze zbioru Erazma Marcinowskiego widnieje zapis stwierdzający ich przynależność do osoby właściciela, np.: „M. Erasmus Marczinowski canonicus ecclesiae collegiatae Tarnoviensis" ${ }^{41}$. Na kilku zakupionych przez siebie dziełach Erazm Marcinowski pozostawił identyczny w treści zapis, jednakże podkreślając, iż księgę zakupił dla siebie i swoich przyjaciół, którzy będą z niej korzystać. Na wszystkich egzemplarzach wpisał też pełną datę. Na dziele Controversiam de Eucharistiae [...] (Kolonia 1584) zapisał: „M. Erasmus Marczinowskij me suo suorumque amicorum in postarum paravit usui flor. 1, gross.4, dono anni 1584, die 24 mensis septembra"42, a na trzech tomach dzieła Alojzego Lippomana Vitarum Sanctorum Patrum [...] (Wenecja 1556) pozostawił podobny w brzmieniu zapis z widoczną datą: „Die10 mensis Octobris anno salutis recuperatione 1582" (t. 5) "Die 10 mensis Octobris Anno Partus Virginei 1582" (t. 8$)^{44}$ oraz „die 10 mensis Octobris Annorum et salutotionis 1582”(t. 6$)^{45}$.

${ }^{38}$ BWSDT/SD, sygn. 65.

${ }^{39}$ Statuta nec non liber promotionum philosophorum ordinis in universitate studiorum Jagellonica ab anno 1402 ad annum 1849, wyd. J. Muczkowski, Kraków 1849, s. 217. F. Herzig nie odnotowuje obecności kanonika Erazma Marcinowskiego w pracy Katedra niegdyś kolegiata w Tarnowie, jednakże potwierdzeniem, iż był kanonikiem kolegiaty tarnowskiej, są zachowane wpisy własnościowe na jego książkach.

${ }^{40}$ BWSDT/SD, sygn. 3119; BWSDT/SD, sygn. 3102.

${ }^{41}$ BWSDT/SD, sygn. 229.

${ }^{42}$ BWSDT/SD, sygn. 226.

${ }^{43}$ BWSDT/SD, sygn. 329.

${ }^{44}$ BWSDT/SD, sygn. 330.

${ }^{45}$ BWSDT/SD, sygn. 331. 
Z proweniencją kanonika Erazma Marcinowskiego trafiło do zbiorów biblioteki kapitulnej łącznie osiem ksiąg z zakresu liturgii, teologii, patrystyki, biblistyki oraz żywotopisarstwa. Pochodzą one ze znaczących XVI-wiecznych oficyn wydawniczych Wenecji, Rzymu, Kolonii, Lyonu oraz z Brześcia nad Bugiem ${ }^{46}$. Są to m.in. dzieła: Gabriela Biela, Sacri canonis Missae [...] (Brixiae 1576) z zapisem na karcie tytułowej przynależności księgi do Erazma Marcinowskiego: „M. Erasmus Marczinowski ecclesiae Collegiatae Tarnoviensis pro usu can. Legavit" ${ }^{47}$,Bernardusa Bonioannesa, Epitomae in universam Sacrosanctae Theologiae [...] (Lyon 1579) z widocznym zapisem: „Erasmus Marczinowski canonicus ecclesiae collegiatae Tarnoviensis" ${ }^{\text {"2 }}$, jednoznacznie określającym godność jej właściciela. Identyczny w treści zapis pozostawił Erazm Marcinowski również na dziele Antoniusa Florentinusa Summae sacrae theologiae, iuris Pontificii et cesarei [...], t. 3-4 (Wenecja 1581-1582) oraz Corneliusa Janseniusa Commentariorum in suam concordiam [...] (Lyon 1582), na dziele Florentczyka dodając jedynie formę legavit ${ }^{49}$, na księdze zaś Janseniusa „Per usum, legavit”50. Erazm Marcinowski dbał również o oprawę zakupionych dzieł. Wszystkie księgi z jego kolekcji wyróżniają się identyczną, piękną oprawą renesansową, z widocznymi mosiężnymi narożami i guzem środkowym, wszystkie też były zamykane na dwie bądź jedną klamerkę - co istotne - służyły właścicielowi, który pozostawił w tekście liczne podkreślenia i uwagi marginalne świadczące o lekturze dzieła.

\section{Księgozbiór kolegium wikariuszy tarnowskich}

Trzeba podkreślić, że oprócz zgromadzonego księgozbioru kapitulnego swoje księgi posiadało również kolegium wikariuszów utworzone - jak wspomniano wyżej - 10 lipca 1458 roku. Odpowiedzialnym za nie był każdorazowo tzw. starszy (senior) wybrany spośród kolegium. Pierwszy potwierdzony spis książek pochodzi z 1602 roku i został sporządzony na okoliczność przekazania zarządu nad majątkiem kolegium wikariuszów (w tym ksiąg) nowo wybranemu seniorowi kolegium, ks. Marcinowi Dramskiemu ${ }^{51}$, co odnotowano:

[...] regestr spisany wszystkich rzeczy wikariuszów, które są oddane od $\mathrm{x}$.

Jana Bieleckiego, (pacanowskiego?) plebana skrzyszowskiego [...] starszego

wikarego kościoła tharnowskiego do ręki x. Marcina Dramskiego, starszego

wikariów kościoła tharnowskiego $[\ldots]^{52}$.

Księgi zgromadzone przez wikariuszów były przechowywane w osobnym, murowanym budynku, tuż obok kolegiaty tarnowskiej. Była to tzw. wikariówka i jak zapisano:

\footnotetext{
${ }^{46}$ S. Kotarski, Brixiae (Brescia), Brześć n/Bugiem, w: Stownik zlatynizowanych nazw miejscowości ze szczególnym uwzględnieniem osiedli słowiańskich, Warszawa 1955, s. 12.

${ }^{47}$ BWSDT/SD, sygn. 354.

${ }^{48}$ BWSDT/SD, sygn. 229.

${ }^{49}$ BWSDT/SD, sygn. 3119; BWSDT/SD, sygn. 3102.

${ }^{50} \mathrm{BWSDT} / \mathrm{SD}$, sygn. 6445.

${ }^{51}$ ADT, Bibliotheca vicariorum Tharnoviensis, w: Documenta ecclesiae collegiatae tarnoviensis, sygn. I. 3, k. 104.

${ }^{52}$ Tamże.
} 
[...] wejście do tego domu jest kamienne, dobre, mające zamek, stępy u drzwi do którego każdy vicarius ma klucz communitatis. Izba na dole z zamkiem communitatis w której piec był pierwej ziemny a teraz kaflowy, dobry. Okna ma dobre, weneckie. Obrazy trzy. Jeden św. Piotra, drugi św. Anny, trzeci obraz św. Agnes x. Piotra Rajskiego, wikarego tam jest. Tamże jest biblioteka wikaryjska $[\ldots]^{53}$.

Księgozbiór wikaryjski przechowywany był w niewielkim pomieszczeniu dość skromnie wyposażonym w niezbędne meble, tj. stary stół w stylu flandryjskim, stojący w sieni budynku, większy zydel przeznaczony dla dwóch osób oraz dwa małe pojedyncze zydelki. Pomieszczenie biblioteki było jasne, szczególnie w okresie zimowym i latem, co odnotowano:

[...] biblioteka wikaryjska w szafie pod regestem ksiąg. Ta izba w zimie i lecie jasną jest. Stół flandrowy roboty staroświeckiej w sieni, dobry, zydel na dwie osoby, zydelków dwa na jedną osobę $[\ldots]^{54}$.

Księgi przechowywano w szafie.

W spisanym w 1602 roku regestrze wszystkich rzeczy należących do kolegium wikariuszów kolegiaty tarnowskiej został również umieszczony wykaz przechowywanych wówczas ksiąg. Łącznie wykazano 23 dzieła ${ }^{55}$ zarówno rękopiśmienne, jak i drukowane $\mathrm{z}$ zaznaczeniem jedynie przy niektórych formatu, np. in folio. Na końcu spisujący odnotował 24 księgi jako manuskrypty, a zatem gdyby nie była to pomyłka, to liczba spisanych dzieł podwoiłaby się.

W regestrze zatytułowanym Bibliotheca Vicariorum Tharnoviensem odnotowano następujace księgi, nie podając ich pełnego tytułu, miejsca i roku wydania ani oficyny wydawniczej ${ }^{56}$ :

1) Biblia Sacra in folio scripta ${ }^{57}$,2) Sermones discipuli de tempore in folio ${ }^{58}, 3$ )

Sermones Vincenti de tempore et sanctis ${ }^{59}$, 4) Sermones thesauri de tempore et de sanctis $\left.{ }^{60}, 5\right)$ Speculum exemplorum ${ }^{61}, 6$ )Sermones Quadragesimale Roberti, ${ }^{62} 7$ ) Sermones Quadragesimale ${ }^{63}, 8$ ) Sermones de passione Christi, scripti ${ }^{64}$,

${ }^{53}$ Tamże, k. 102.

${ }^{54}$ Tamże.

${ }^{55}$ Tamże, k. 104.

${ }^{56}$ Tamże, k. 105.

${ }^{57}$ Zapewne była to Biblia przepisana ręcznie, stąd zapis scripta (manuskrypt).

${ }^{58}$ Ioannes Herolt, Sermones discipuli de tempore et de sanctis cum promptuario exemplorum et de Beata Virgine. Tarnowski egzemplarz pochodzi ze Strasburga (Typ. Paludani, 1484). Zachowany do czasów współczesnych w Bibliotece Wyższego Seminarium Duchownego.

${ }^{59}$ Vincentius Ferrerius, Sermones de Tempore et de Sanctis, [b.m., b.r.].

${ }^{60}$ Pseudo-Petrus de Palude, Sermones Thesauri novi de tempore, [b.m., b.r.].

${ }^{61}$ Speculum exemplorum (Zwierciadło przykładów) - tarnowski egzemplarz pochodzi z oficyny Richarda Pafraeta z 1481 r. Zachowany do czasów współczesnych w Bibliotece Wyższego Seminarium Duchownego.

${ }^{62}$ Caracciolus Robertus, Sermones quadragesimales de peccatis, [b.m., b.r.].

${ }^{63}$ Pelbartus de Themeswar, Sermones Pomerii de Sanctis, [b.m., b.r.].

${ }^{64}$ Zapewne jest to dzieło Guiliemusa Textora, Sermo de Passione Christi będące w posiadaniu kanoników tarnowskich jako manuskrypt (scripti). 
9) Sermones de tempore et de sanctis Paratii in octavo ${ }^{65}$, 10) Celi[nieczyt.] in quarto, 11) Homiliarius ${ }^{66}$, 12) Opera sermonum de Palude ${ }^{67}$, 13) Sermones Nicolai Wilkowecko; 14) Concordantiae breviores, 15) De imitatione Christi ${ }^{68}$, 15) Dni Clemens Constitutiones $\left.{ }^{69}, 16\right)$ Sermones Joannis Feriii ${ }^{70}$, 17) Thomus secundus Jacobi Scaplerii, 18) Hosius,Confutatio prolegomenon Brentii ${ }^{71}$, 19) Albertii Novicampianus, Scopus Bibliorum Veteris et Novi Testamenti ${ }^{72}$, 20) Quadregasimale Roberti Bellarmini,Historia explanatio ${ }^{73}$, 21) Homiliae Haymonis in Evangelia ${ }^{74}$, 22) Librii Cantorum 4 aliis $5^{75}$, 23) Librii 24 scripti $[\ldots]^{76}$.

Spisujący inwentarz nie wyodrębnił ksiąg rękopiśmiennych, zaznaczył jedynie przy Biblii oraz przy opisie Sermones passione, iż te są scripti, ponadto na końcu spisu zaznaczył lakonicznie, iż 24 bliżej nieokreślone księgi są również scripti, a zatem zakwalifikował je jako manuskrypty. Przy księgach drukowanych nie zaznaczył miejsca wydania, oficyny wydawniczej i roku ukończenia druku. Spis miał charakter pobieżny (lakoniczny) i sporządzono go z polecenia prepozyta kapituły kolegiackiej w Tarnowie $\mathrm{z}$ chwilą objęcia funkcji seniora w kolegium wikariuszów przez nowego kapłana. W regestrze ksiąg widoczne są niedociągnię-

${ }^{65}$ Paratus, Sermones de tempore et de sanctis, [b.m., b.r.].

${ }^{66}$ Homiliarius doctorum a Paulo diacono collectus, [b.m., b.r.].

${ }^{67} Z$ uwagi na brak daty i miejsca wydania, trudny do pełnej identyfikacji, zapewne chodzi o Sermones Thesauri novi de tempore.

${ }^{68}$ De imitatione Christi. - Ioannes Gerson: de meditatione cordis, [b.m., b.r.].

${ }^{69}$ Clemens V papa, Constitutiones, [b.m., b.r.].

${ }^{70}$ Ioannes Ferrariensis, Sermones, [b.m., b.r.].

${ }^{71}$ Stanisław Hozjusz (1504-1579) - biskup chełmiński, później warmiński, kardynał, dogmatyk, polemista, czołowy przedstawiciel reformy katolickiej w Polsce, Sługa Boży, autor wielu dzieł teologicznych, szczególnie w dziele zwalczania szerzącego się protestantyzmu. Dzieło, które było w posiadaniu kolegium wikariuszy w Tarnowie to Confutatio prolegomenon Brentii (wyd. w Kolonii w 1560). Zob. H.E. Wyczawski (red.), Hozjusz Stanisław (1504-1579), w: Stownik Polskich Teologów Katolickich (dalej: SPTK), t. 2, Warszawa 1982, s. 68-75.

${ }^{72}$ Alberus Novicampianus (Wojciech Nowopolczyk) (ok.1504-1559) - doktor medycyny, filo$\log$, teolog, wykladowca greki na Uniwersytecie Krakowskim, nauczyciel Jana Zygmunta, syna króla węgierskiego Jana Zapolyi, autor wielu znakomitych ksiąg z zakresu medycyny, literatury i teologii. W tym m.in. znamienitego dzieła z 1553 r., będącego podsumowaniem nauki chrześcijańskiej Scopus Biblicus Veteris et Novi Testamenti cum Anntationibus sum mam doctrinae Christianae, w którym zastosował nowoczesną metodę biblijną. U współczesnych sobie cieszył się dużym uznaniem jako drugi - obok Stanisława Sokołowskiego - najwybitniejszy teolog uniwersytecki. Zob. H.E. Wyczawski (red.), Nowopolczyk Wojciech (ok. 1504-1559), SPTK, t. 3, Warszawa 1982, s. 233234.

${ }^{73}$ Jest to dzieło Roberta Bellarmina (1542-1621), włoskiego jezuity, później kardynała, wybitnego teologa polemisty, pt. Explanatio in Psalterium, nie zaznaczono miejsca i roku wydania.

${ }^{74}$ Być może chodzi o dzieło niemieckiego benedyktyna Haymo de Halberstadt (778-853), noszące tytuł: D. Haymonis, Episcopi Halberstatensis, Homilia in Evangelia Dominicalia, wyd. w Paryżu w $1555 \mathrm{r}$.

${ }^{75}$ Odnotowano cztery lub - jak zapisano - być może pięć ksiąg służących do śpiewu liturgicznego wykonywanego podczas nabożeństw w kościele kolegiackim w Tarnowie.

${ }^{76}$ Zapewne zapis dotyczył odnotowania 24 manuskryptów, które spisujący potraktował zbiorczo, nie wymieniając choćby lakonicznie tytułu kodeksu. 
cia i niedbałość przy zapisie autorów i tytułów ich dzieł, np. przy osobie Alberta Novicampinusa nie został uwzględniony żaden tytuł, kilka linijek zaś niżej odnotowano jako odrębną książkę Scopus Biblicus Veteris et Novi Testamenti cum Anntationibus sum mam doctrinae Christianae, zapewne skryptor kolegiacki pomylił się i nieuważnie zapisał tytuł dzieła bez podania przy nim autorstwa Wojciecha Nowopolczyka.

Zgromadzone przez kolegium wikariuszów księgi pełniły funkcję praktyczną, służąc pomocą w duszpasterstwie parafialnym, na co wskazuje duża liczba sermones, homiliariów, oraz thesarusy i nade wszystko Biblia. Był to rodzaj księgozbioru podręcznego, służącego przede wszystkim do głoszenia kazań niedzielnych i w okresie Wielkiego Postu. I choć nie ma odnotowanych dat ukończenia druku, nie ma wątpliwości, że w zdecydowanej większości były to księgi XV-wieczne (inkunabuły), dość rozpowszechnione w tym czasie zarówno w środowisku kościelnym diecezjalnym, jak i zakonnym.

W tarnowskim księgozbiorze wikariuszów kolegiackich w początkach XVII stulecia były więc obecne księgi, których autorami byli m.in. średniowieczny dominikański kaznodzieja Wincenty z Ferrary (1350-1419), węgierski minoryta Pelbartus de Themeswar (1430-1504) czy francuski dominikanin, teolog, filozof i kaznodzieja - Petrus de Palude (ok. 1277-1342).

Duchowni często wypożyczali księgi, które służyły im przez dłuższy czas w pracy, z reguły po ich śmierci księgi wracały do biblioteki kolegium. Tak było choćby w przypadku ks. Jakuba Andrzejowity, po śmierci którego kilka egzemplarzy Sermones różnych autorów zostało w 1621 roku zwróconych do wspólnego zasobu biblioteki wikariuszowskiej ${ }^{77}$, co skrupulatnie odnotowano w regestrze:

[...] post mortem autem R. P. Jacobi Anrzeiovitae vicepraepositi et senioris vicarium hoc [nieczyt.] Anno Dni 1621, die 20 nov. Odebrałem tę księgę od x. Jacoba Andrzejowity, Sermones [...], Thesaurus de tempore et de sanctis, Sermones Ecckij,Sermones Roberti, Sermones Vincentii, pars hyemalis $[\ldots]^{78}$.

Jeszcze za życia duchowni kolegiaccy zapisywali należące do nich księgi $\mathrm{w}$ formie legatu testamentowego utworzonej przy kolegium bibliotece. Był to zwyczaj powszechnie praktykowany. Do wykonania ostatniej woli testatora wyznaczani byli egzekutorzy testamentu, których powinnością było jej wypełnienie. Z połowy XVII wieku pochodzi dość znaczny legat testamentowy do księgozbioru kolegium wikariuszów po zmarłym księdzu Piotrze Ratyńskim, który pełnił funkcję wiceprepozyta i seniora wikariuszów w kolegiacie tarnowskiej:

${ }^{77}$ Tamże.

${ }^{78}$ Tamże. Przy takim ogólnym zapisie tytułów trudno jednoznacznie określić autorów poszczególnych sermones, jedynie nie nasuwa wątpliwości zapis Sermones Vincentii. Jest to dzieło dominikańskiego kaznodziei, Wincentego z Ferrary, Sermones de tempore et de sanctis, wydane w bliżej nieznanej oficynie, gdyż mogło ukazać się drukiem m.in. w Kolonii, Norymberdze, Strasburgu, niestety nie odnotowano również daty rocznej wydania dzieła. 
[....] R. Pater Petrus Ratynski vicepraepositi et senior vicarium non post mortem offeret A. Dni 1652 non tantem Bibliotheca eius sed alia necessam adveherunt communitate vicariorum $[\ldots]^{79}$.

Nie jest podana dokładna data przekazania ksiąg, ale na podstawie tytułów można wnioskować, iż najwcześniej mogło mieć miejsce w pierwszej połowie XVII wieku.

Podobnie jak w spisie z 1602 roku księgi przekazane przez ks. Piotra Ratyńskiego do biblioteki kolegium wikariuszów były spisane pobieżnie, bez podania imienia bądź nazwiska autora dzieła, tytułu, miejsca wydania, oficyny wydawniczej czy roku. W sporządzonym spisie nie uwzględniono też rozróżnienia na manuskrypty i księgi drukowane, nie uczyniono również jakiejkolwiek wzmianki, czy księgi posiadały stare, cenne oprawy. Dla spisującego regestr nie miało to większego znaczenia. Zamieszczony spis dzieł w Documenta ecclesiae collegiatae tarnoviensis zatytułowano: „Xięgi po Nieboszczyku Xiędzu Pietrze od Egzekutorów dane Oycom Vicariom Tharnowskim" ", poniżej zaś, nie stosując kolejności numerycznej, zostały lakonicznie spisane księgi. Wielu autorów ksiąg bądź ich tytułów nie da się na podstawie tego spisu bezbłędnie odtworzyć.

1) Dictionarius Calepini ${ }^{81}$, 2) Granatensis, Sermones ${ }^{82}$, - (loci communes),

3) Kazania Polskie Skargi, 4) Opera sermonum de Palude, 5) Sermones thesauri de tempore et de sanctis, 6) Sermones Quadragesimale,7) Francisci Costerii, Opusculum, 8) Promptuarium catholicum opera, 9) Homiliae Ludovici Granatensis, 10) Interpretationes Quadragesimales quartus tomus, 11) Sermones Petri de Palude ${ }^{83}$, 12) Conceptus theologici, 13) Postilla Francisci, 14) Compendium Novum Diurnale, 15) Concionatorum, 16) Conciones Tridentini, 17) Sermones de tempore et de sanctis Paratii, 18) Commentarius, 19) Rudolphi, Homiliae, 20) Postilla Polska, 21) Joannes Mat[...] Conciones, 22) Nauka umierania, 23) Salomonis proverbia, 24) Scrutinium sacerdote, 25) Postilla, 26) Ius Tridentinium Sacerdotum, 27) Syntaxes ilias miraculis, 28) Rudolphi adversus z Dialogus, 29) Polska Regna, 30) Homilia in Evangelia Rudolphi, 31) Conceptus Theologicus, 32) De vita miraculis, 33) Psalterio Davidow, 34) Thesaurus Exorcismorum, 35) Petri, Flores sermones, 36) Elementa ad confessiones Petri Canisii libri 5, 37) Quinti Cur[nieczyt] de rebus gestis, 38) Sermo Petri de Palude, 39) Ordo Missae, 40) Conceptus Theologici, 41) Biblia, 42) Homiliae Joannes Ecckij, 43) Contoversiae Alterii, 44) Vita Vincentius Kadlubkonis, 45) Granatensis, Discipuli sermo, 46) Promptuarium catholicum, 47) Biblia Polska, 48) Sermones de sanctis, 49) Osorio Hieroni-

${ }^{79}$ ADT, Bibliotheca vicariorum Tharnoviensis, w: Documenta ecclesiae collegiatae tarnoviensis, sygn. I. 3, k. 104.

${ }^{80}$ ADT, Księgi po nieboszczyku księdzu Piotrze od egzekutorów dane ojcom vikariuszom Tharnowskim, w: Documenta ecclesiae collegiatae tarnoviensis, sygn. I. 3, k. 105.

${ }^{81}$ Ambrosius Calepinus, Dictionarium undecim linquarum, Paryż 1586.

${ }^{82}$ Ludvicus Granatensis, Concionum in Evangelia que per totum diebus Dominicis, Mediolan 1588. Por. zapisy poz. 2, 9, oraz 45.

${ }^{83}$ Pseudo-Petrus de Palude, Sermones Quadragesimales Thesauri novi, [b.m., b.r.]. Najprawdopodobniej spisujący popełnił błąd, gdyż przy w spisie poz. 4 i 6 zapewne chodzi o dzieło Paludanusa zapisane niestarannie, stąd nie można go jednoznacznie określić; por. poz. 4) Opera sermonum de Palude; poz. 6) Sermones Quadragesimale oraz poz. 38) zapis: Sermo Petri de Palude. 
mo, Opera quattuor, 50) Rationale seu enchiridionGuillelmi $\left.{ }^{84}, 51\right)$ Libri quinque manualis Christianorum, 52) D. Haymonis eppiscopis, [pars affinalis?] 53) Aennei Seneca, 54) Libellus Christianum Meditationes, cordis $^{85}$, 55) Sermones de Privilegium [nieczyt.], 56) Proffessio catholicae doctrinae Francisci Cvinlgi, 57) Cathechismus polonicus idiomate in folio ${ }^{86}$.

Jak wynika z zachowanego spisu, dominowały księgi w języku łacińskim, zaledwie kilka było w języku polskim. Od strony tematycznej były to wszelkie odmiany kaznodziejstwa, poczynając od średniowiecznych sermones, które wykorzystywano do głoszenia kazań, ponadto popularne od średniowiecza postylle, żywoty i miracula, katechizmy Kościoła katolickiego, mszały, brewiarze, słowniki, thesaurusy i komentarze biblijne. Kilka ksiąg to bez wątpienia druki XV-wieczne (inkunabuły). Wśród przekazanych znalazły się też druki XVI i XVII-wieczne, w tym Biblia wydana w języku polskim, najprawdopodobniej w przekładzie Jakuba Wujka z 1599 roku $^{87}$ oraz tegoż autora Postilla catholica to jest kazania na każdą niedzielę i każde święto, wydana w Krakowie w 1573 roku w oficynie Mateusza Siebeneychera. W spisie odnotowano również bardzo popularne Kazania na niedzielę $i$ święta Piotra Skargi ${ }^{88}$. Godna zauważenia w zbiorze księdza Piotra Ratyńskiego jest obecność Żywotu Wincentego Kadłubka (Vita et miracula servi Dei Vincentii Kadtubkonis ${ }^{89}$, biskupa krakowskiego, następnie cystersa jędrzejowskiego, a przede wszystkim kronikarza dziejów Polski, pióra polihistora Szymona Starowolskiego. Dzieło zostało wydane w Krakowie w 1642 roku. Warto odnotować również obecność wybitnego dzieła z dziedziny leksykografii autorstwa Ambrożego Calepinusa (1435-1510) Dictionarium undecim linquarum, wydanie paryskie z 1586 roku oraz dzieła Ludwika z Granady (1504-1588) Concionum in Evangelia que per totum diebus Dominicis, wydane w Mediolanie w 1588 roku, które wpisywało się w nurt nowoczesnego kaznodziejstwa. W spisie ksiąg odnotowane zostało jako Granatensis Sermones (poz.2), a poniżej jako Homiliae Ludovici Granatensis (poz.9) oraz Granatensis, Discipuli sermo (poz.45).

Dar ten, bardzo bogaty, obejmujący ponad 50 pozycji, był dużym wzmocnieniem zasobu biblioteki kolegium. Przy okazji informacji o przekazaniu ksiąg odnotowano informację o ich przechowywaniu: ,[...] Te wszystkie są w izbie communitaty na dole w szafie sub regestro eodem $[\ldots]^{\prime 90}$.

${ }^{84}$ Duranti Guillelmus, Rationale divinorum officiorum, [nie podano m. wyd. i r. wyd.].

${ }^{85}$ De imitatione Christi. - Ioannes Gerson: De meditatione cordisi, [brak m. wyd. i r. wyd.].

${ }^{86}$ Tamże.

${ }^{87}$ Przy opisie Biblii nie podano żadnych dokładniejszych danych, kiedy i gdzie była wydana, jedynie określenie ,polska”, stąd domniemanie, iż może być to Biblia w przekładzie jezuity ks. Jakuba Wujka, wydana w Krakowie, w oficynie Łazarzowej w 1599 roku.

${ }^{88}$ Podobnie lakoniczny opis dotyczy dzieła Piotra Skargi. Można domniemywać, że mogły to być Kazania na niedzielę $i$ święta całego roku, których pierwsze wydanie miało miejsce w 1595 roku.

${ }^{89}$ Szymon Starowolski, Vita et Miracula Servi Dei Vincentii Kadlubkonis, w Krakowie, In Officina Christophorii Schedelij 1642.

${ }^{90}$ ADT, Księgi po nieboszczyku księdzu Piotrze od egzekutorów dane ojcom vikariuszom Tharnowskim, w: Documenta ecclesiae collegiatae tarnoviensis, sygn. I. 3, k. 105. 
Warto zaznaczyć, iż księgi kolegium wikariuszów z czasem zasiliły księgozbiór kapituły kolegiackiej, a następnie katedralnej tarnowskiej. W XIX wieku, gdy tworzono bibliotekę seminarium tarnowskiego, księgi po wikariuszach kolegiackich zostały przekazane do księgozbioru seminaryjnego, gdzie znajdują się do dziś. Kilka najcenniejszych z tego zasobu to księgi XV-wieczne, na których zapisano: „Liber ecclesiae Tharnowiensis”. Taki zapis można odnaleźć na dziełach: Speculum exemplorum, wydanym przez Ryszarda Pafraeta w Deventer 1481 roku $^{91}$; Wincentego z Ferrary, Sermones de tempore et de sanctis, wydanym przez Henryka Quentella w Kolonii w 1487 roku $^{92}$, Biblii w norymberskim w wydaniu Antoniego Kobergera z 1480 roku $^{93}$ oraz późniejszym (bazylejskie) wydaniu Biblii z 1491 roku z oficyny Jana Amerbacha ${ }^{94}$, ponadto Pelbarta de Themeswar Sermones Pomerii et de Sanctis (Hagenau, Henryk Gran i Jan Rynman 1500) ${ }^{95}$ i Pseudo-Petrusa de Palude Sermones Quadragesimales Thesauri novi, wydanym w Strasburgu w 1485 roku $^{96}$.

W przeciwieństwie do ksiąg po kanonikach tarnowskich, gdzie na podstawie zachowanych zapisów proweniencyjnych można prześledzić drogę książki, jej użytkowanie w dawnych wiekach, oprawę czy zapisy marginalne, księgi po wikariuszach kolegiaty tarnowskiej w wielu wypadkach są trudne do zidentyfikowania na podstawie lakonicznych zapisów w inwentarzu. Z kolei na kartach tytułowych zachowanych ksiąg praktycznie nie ma wpisów proweniencyjnych, wskazujących na ich dawnego właściciela, jedynie lakoniczny zapis na karcie tytułowej „Liber ecclesiae Tharnoviensis” lub „Libri vicariorum ecclesiae Tharnoviensis" sugerujący, że księga mogła być własnością kolegium wikariuszów tarnowskich. Sądząc po zachowanych księgach i ich autorach, był to zdecydowanie księgozbiór pragmatyczny, podręczny, wykorzystywany w pracy duszpasterskiej przez wikariuszów w dawnych wiekach wśród społeczności lokalnej prywatnego miasta, jakim był wówczas Tarnów, i w jego kościele kolegiackim pw. Narodzenia Najświętszej Maryi Panny.

\section{BIBLIOGRAFIA}

\section{Źródla}

Archiwum Diecezji Tarnowskiej (ADT)

sygn. I. 3, k. 104, Bibliotheca vicariorum Tharnoviensis, w: Documenta ecclesiae collegiatae tarnoviensis.

sygn. I. 3, k. 206, Erectio ecclesiae colegiatae Tarnoviensis descripta, w: Documenta ecclesiae collegiatae tarnoviensis.

\footnotetext{
${ }^{91}$ BWSDT/INC, sygn. 5427.

${ }^{92}$ BWSDT/INC, sygn. 5111.

${ }^{93}$ BWSDT/INC, sygn. 6474

${ }^{94}$ BWSDT/INC, sygn. 6481.

${ }^{95}$ BWSDT/INC, sygn. 6482.

${ }^{96}$ BWSDT/INC, sygn. 510.
} 
sygn. I. 3, k. 105, Księgi po nieboszczyku księdzu Piotrze od egzekutorów dane ojcom vikariuszom Tharnowskim, w: Documenta ecclesiae collegiatae tarnoviensis.

sygn. I. 3, k. 1-8, Privilegium erectionis vicariorum Tharnoviensem in titulum perpetuitatis, w: Documenta ecclesiae collegiatae tarnoviensis.

Statuta nec non liber promotionum philosophorum ordinis in universitate studiorum Jagellonica ab anno 1402 ad annum 1849, wyd. J. Muczkowski, Kraków 1849.

\section{Opracowania}

Herzig Franciszek, Katedra niegdyś kolegiata w Tarnowie wraz z krótka wzmianka o innych kościołach tarnowskich, Tarnów 1900.

Hornowska Maria, Zdzitowiecka-Jasieńska Halina, Zbiory rękopiśmienne $w$ Polsce średniowiecznej, Warszawa 1947.

Kaliszuk Jerzy, Codices deperditi. Średniowieczne rękopisy łacińskie Biblioteki Narodowej utracone w czasie II wojny światowej, t. 1.: Dzieje i charakterystyka kolekcji, Wrocław 2016.

Kumor Bolesław, Diecezja Tarnowska. Dzieje ustroju i organizacji 1786-1985, Kraków 1985.

Kumor Bolesław, Erekcja kolegiaty i kapituly pod wezwaniem Wszystkich Świętych w Bobowej, „Archiwa, Biblioteki i Muzea Kościelne”, 11 (1965) s. 287-312.

Marszalska Jolanta Małgorzata, Katalog inkunabułów biblioteki Wyższego Seminarium Duchownego w Tarnowie, Tarnów 1997.

Marszalska Jolanta Małgorzata, Starovolsciana $w$ zbiorach starych druków Biblioteki Wyższego Seminarium Duchownego w Tarnowie, „Rocznik Biblioteki Narodowej”, 44 (2013) s. 303-315.

Marszalska Jolanta Małgorzata, Graczyk Waldemar, Zespoły proweniencyjne zasobu inkunabułów i starych druków Biblioteki Wyższego Seminarium Duchownego w Tarnowie. Właściciele, użytkownicy, bibliofile, Warszawa 2017.

Misiurek Jerzy, Hozjusz Stanisław (1504-1579), w: Encyklopedia katolicka, t. 6, red. J. Walkusz, Lublin 1993, kol. 1257-1260.

Rosowski Witold, Solikowski Jan Dymitr (1539-1603), w: Encyklopedia katolicka, t. 18, red. E. Gigilewicz, Lublin 2013, kol. 580-581.

Ruta Zygmunt, Eyczko Marcin h. Sulima (1508-1578), w: Polski Stownik Biograficzny, t. 17, red. E. Rostworowski, Wrocław-Warszawa-Kraków 1973, s. 595.

Salaterski Stanisław, Kolegiata i kapituła św. Matgorzaty P.M. w Nowym Saczu (14481791), Nowy Sącz 1977.

Szymański Józef, Kapituła kolegiacka w Wojniczu 1465-1788, Lublin 1962.

Śliwa Tadeusz, Śliwski Jakub (zm. 1638), w: Encyklopedia katolicka, t. 19, red. E. Gigilewicz, Lublin 2013, kol. 254-255.

Wyczawski Hieronim Eugeniusz (red.), Hozjusz Stanisław (1504-1579), w: Stownik Polskich Teologów Katolickich, t. 2, Warszawa 1982, s. 68-75.

Wyczawski Hieronim Eugeniusz (red.), Nowopolczyk Wojciech (ok. 1504-1559), w: Słownik Polskich Teologów Katolickich, t. 3, Warszawa 1982, s.233-234.

Zachorowski Stanisław, Rozwój i ustrój kapituł polskich $w$ wiekach średnich, Kraków 1912. 


\title{
THE BOOK COLLECTION OF THE CANONS AND CURATES OF THE TARNÓW COLLEGIATE CHAPTER OF THE NATIVITY OF THE BLESSED VIRGIN MARY (FROM THE FIFTEENTH TO THE EIGHTEENTH CENTURY) IN THE LIBRARY OF THE TARNÓW SEMINARY
}

\begin{abstract}
Summary
When the Tarnów collegiate church was established (1400), a reference library necessary for pastoral work was amassed. The collection contained the Bible, commentaries on biblical texts, philosophical and theological treatises, and books helpful in preaching, including treaties in the field of polemic theology. It grew steadily in size, especially thanks to gifts and bequests made by the Tarnów canons. Among the books of the Tarnów canons are two significant and valuable collections (due to their interesting bindings), which belonged to Szymon Starowolski and Erazm Marcinowski. These are works in the fields of history, preaching, law, biblical literature, and above all, liturgy. They are printed in Latin and come chiefly from foreign publishing houses: Paris, Antwerp, Basel, Venice, Rome and Verona.

In addition to the chapter library, there was also the library amassed by the college of curates, an institution established on 10 July 1458 and assigned to the collegiate church in Tarnów. The books collected by the college of curates were useful aids in parish pastoral work, as evidenced by the large number of sermons, homilies, all kinds of thesauruses, and above all, the Bible. This library was used primarily for preaching sermons on Sundays and throughout the liturgical year. Over time, the books of the college of curates were incorporated into the library of the collegiate chapter, and then into the library of Tarnów cathedral. In the nineteenth century, when the library of the Tarnów seminary was established, the books of the collegiate curates were given to the seminary book collection, where they are still today.
\end{abstract}

Key words: Tarnów; collegiate church; canons; collegiate chapter; curates; library 